\title{
A Study of the Application of Quality
} Assurance Human Factors and Reliability Principles to the Prevention of Major Environment, Safety and Health Incidents 


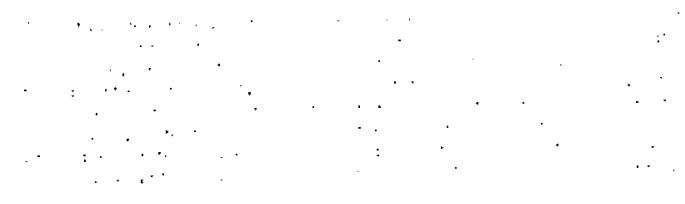

$\therefore 1$ 


\section{ACKNOW LEDGMENTS}

W(- urknowledge, with plcasure, our debt to the members of the Safcty Standards and lingineering wepurtment fur their assistance in obtaining much of the information an which this study is based. 


\section{CONTENTS}

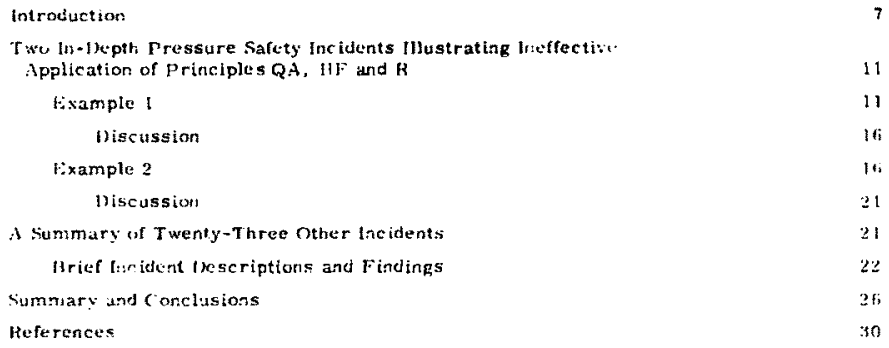

Discuseion

Fxample 2

Discussion

A Summary of Twenty-Three Other lacidents

Hrief listedent treseriptions and Findings 2:

sumnary ind Conclusions

\section{II.LATRNTIONS}

\begin{tabular}{|c|c|}
\hline $\mathbf{1}$ & 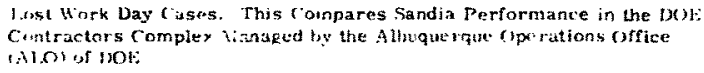 \\
\hline 2 & JisabIing l:ijur Severity Rates \\
\hline 3 & Simplified liew of systems Safety Functions \\
\hline 4 & Alligh-lolucity Propellant ciun System \\
\hline 5 & 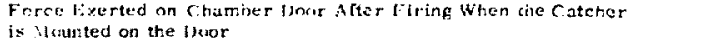 \\
\hline 6 & Sehematic of Cun A sisembly in Ciriginal lowsign Configuration \\
\hline 7 & Impact Chamber rondition at Shot Time Sirown schomatically \\
\hline B & Fuce on (..tamber How in l)esign Change Configuration \\
\hline$\theta$ & Summary of Inadequacius in Example 1 \\
\hline 10 & Fimplificd Senemitic oi a ilvdrogen Furnace lacility \\
\hline 11 & Sutimary of Inadeguas its in Example ? \\
\hline$\because 2$ & Twe Primary Fumetions wa as iskll isserance Program \\
\hline
\end{tabular}

TABIS

Table

I Catr porization of incident Causes 


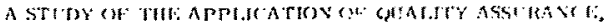

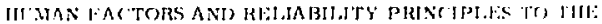

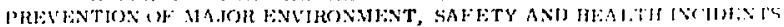

Introdurturn

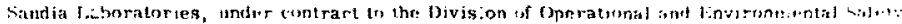

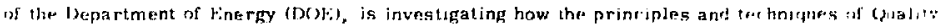

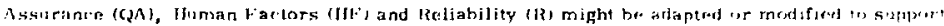

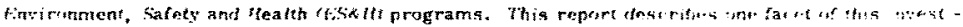

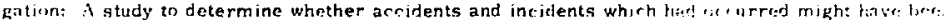

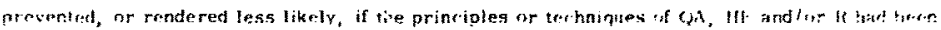

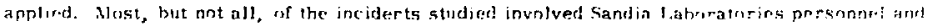
oc-urred at Sandia over the past ten reas.: t.r so.

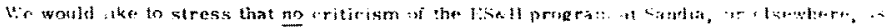

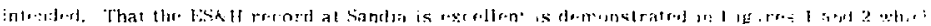

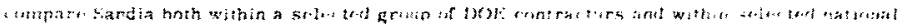
indistrial ratregrirs.

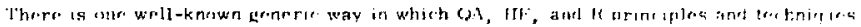

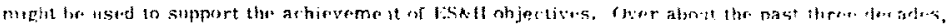

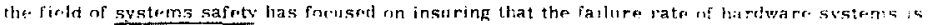

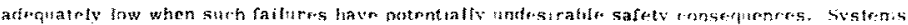

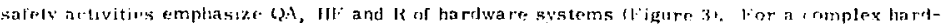

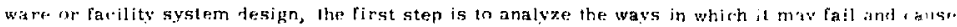

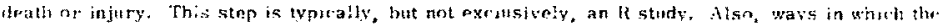

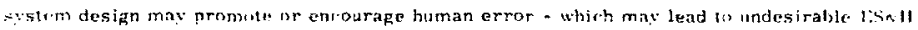

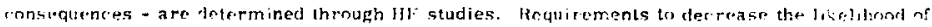

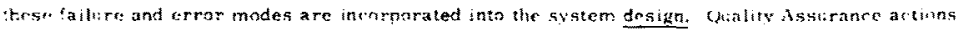
arre iluen taken to verify, independently, that, among ather things

- ite design is, indred, adequate lo artiers drsirnd latels of jisin protertion.

- the design is trily implemented, as production is undertaien, arc:

- He final harduare or facility does truly perform as intended. 


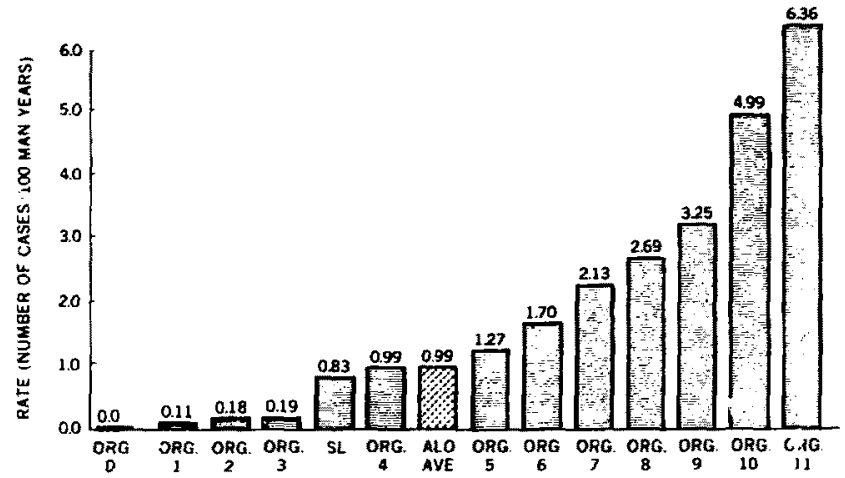

RATAIIIIES MOT liELLLDED
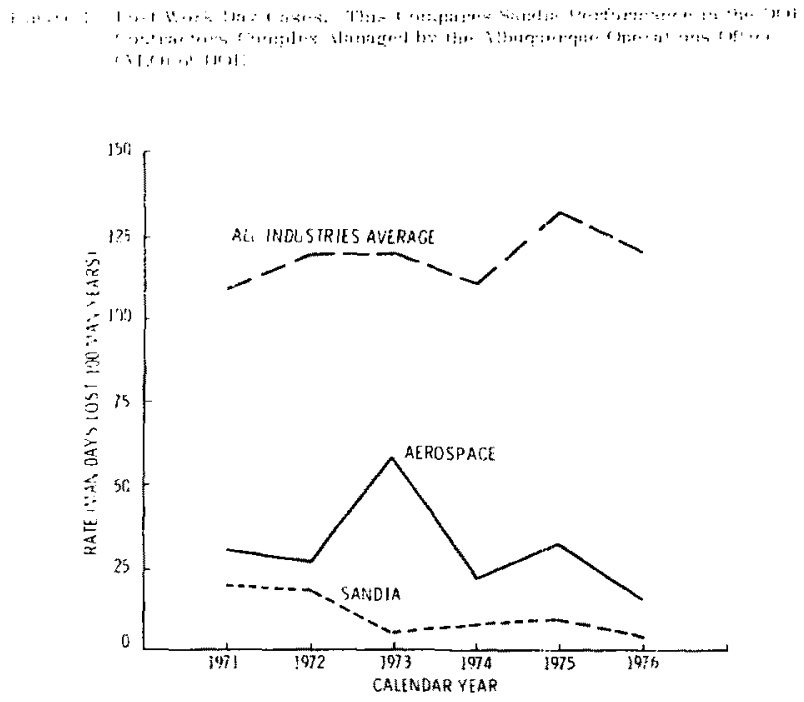

f : 


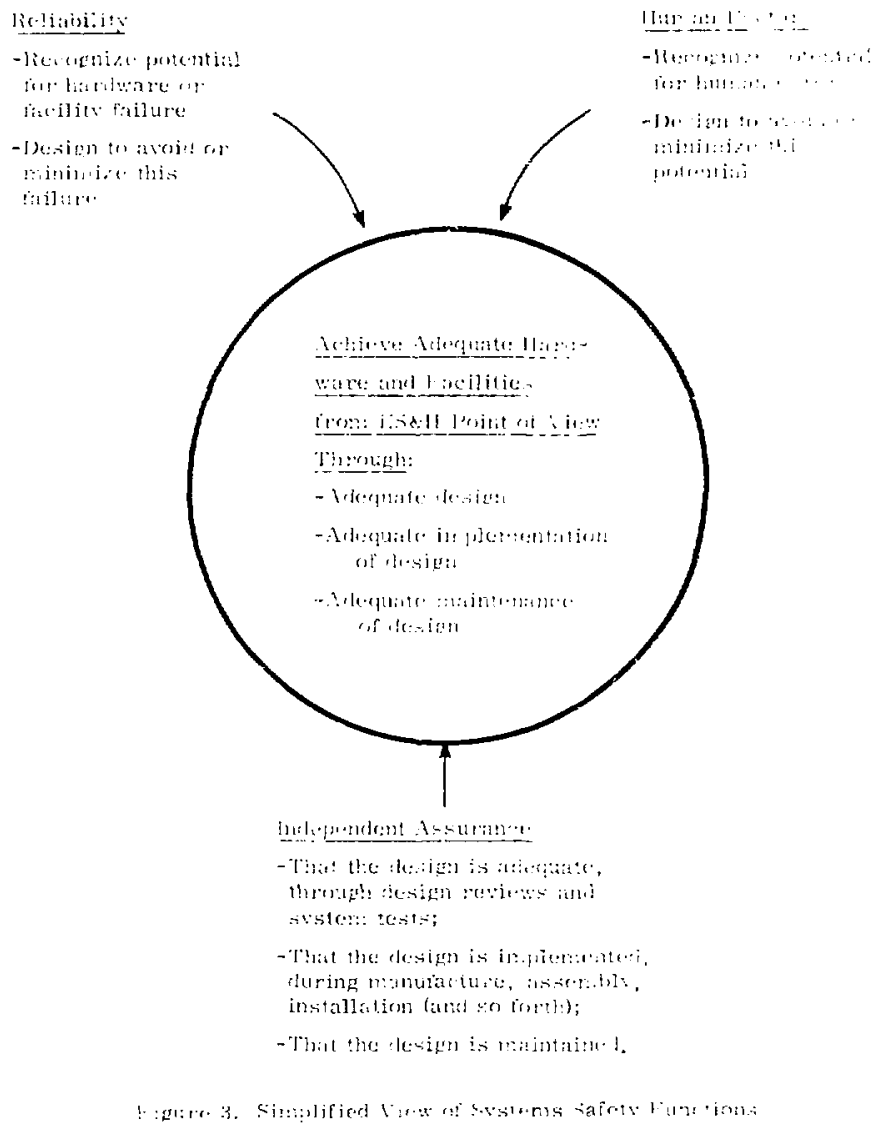


Thus, to arficue safoty objectives, $R$ and $t 1 F$ activitles are used in defining both the needed design (b)jectives ant the actions needed to achieve thum while QA provides independent verifi* rition that the tesign-retated artions are "adtequate" anet are actually "used." Sinme the the tratitinal funtions often found in systems safety activitits include

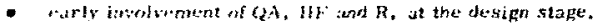

- Hsi; af medes and efferts analyses, fauit trces, and so frirth.

- identification of fuilure modes that lead to unsafo contitions.

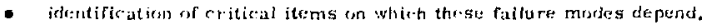

- implementallu or appropriate actions to eliminate thes fajur:

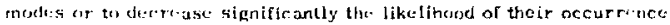
through lin priper thesign or centrol of critical itenis,

- delermintitum inn ancumutation of the risk associated with the finil desight.

- revies se the adequary. manulacturability, assurability and maintainalitity of the design,

- issuranes that the design is ireplemented er that the consequences

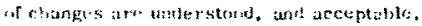

- performinue of systam atod suhsystem tests.

- assuranu thit the nocissary contruls are evercised when the sistent is aperatictiat.

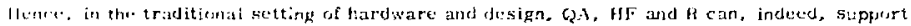

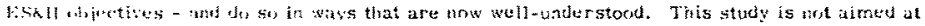

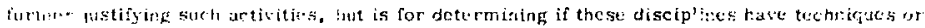

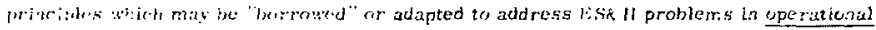

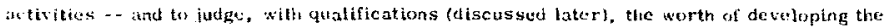
atedin! dichnithues for sucth udaptition.

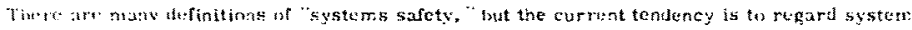
sufuty It thin context. "liskll requilements" are an integral part of "performance requirements." and

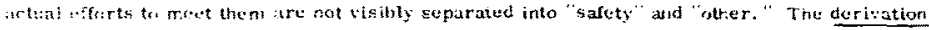
if prianemestijl ins olwe thesse functinss from the above list that are appropriate to a Furticialar systen: Buvond tine definition of requirements, emphasis is placed on tutal design w-

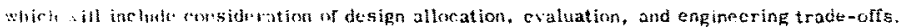

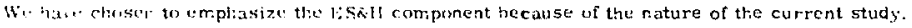


Two In-I.epth Pressure Salety Incidents Illustrating

[neffective Application of Principles $Q A, I I F$ and $R$

\section{Example 1}

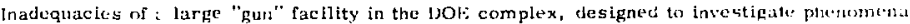
associated w ith ligh-velocity impact (Figure 4)

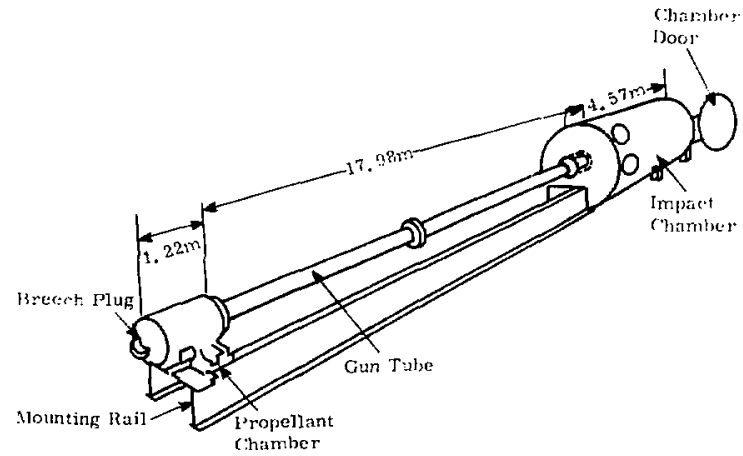

Figur: 4. A ligh-lielocity Propellant Gun System, [n the accident discusstu, energetic gases cescaped from the impact chamber at the right.

The impact rlarther is partially evacuated durirg ar. exprerimert and may contin quit: sensicute instrumentwion to resord whacteristios of the inipict upon a target miteria] from a propectile fired from the gun tube. Explosive charges of up to abeut $4.1 \mathrm{~kg}$ of a nivture of navil propellents are used to iccelerate the projectile into the target. When the progectile leaves the Iun tube, the expansion of the products of "rombustion" of the explosive (hot gases) expand into the impact cliamber and cause a force to bo exerted on the rear donr withe chamber. Ven: personre: ponhativ woutd not adeqlatelv anpreciate that the mpart whambr, for a si:ort time ater firing, becorres a pressure vessel. Figure 5 illustrates this conditinn aud also siows the foree exerted by the impact of the target (fragmentsi on the catcher mounted co the rear don:-

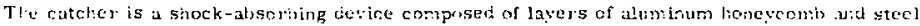
plates. The rear door is hinged and designed to he closed against the chamber hod: with 48 oneincli-diameter bolts. 


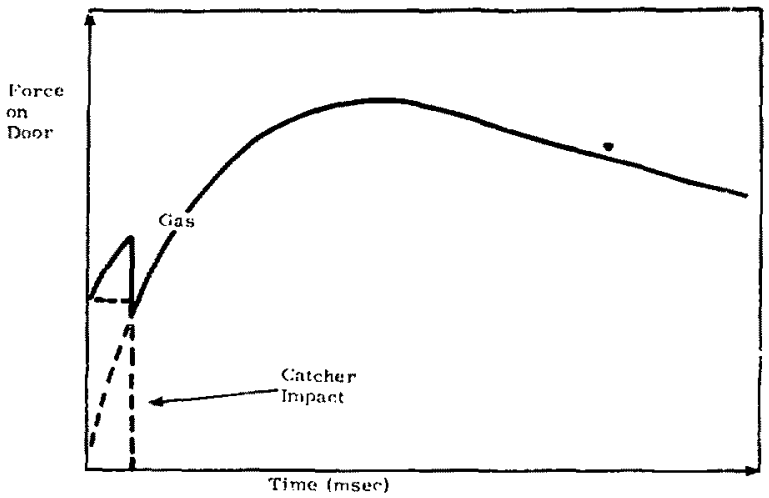

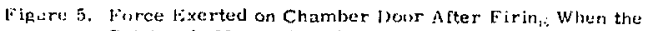
Catcher is Mounted on the Door

Tite design configuration of the impact chamber is shown in simplificd form in i igure F. CNa about 15 vears, experimenters gradually redueed the number of bolts used from 48 to 7. Inting the sime period, instrumentation grew more sophisticated and hand torquina rather thin pheurnatic torquing of the bolts was instituted to avoid disturbing the alignnr., of the instrumentitiom. Safe operating procedures made no mention of the ase of fewer thin the $4 \mathrm{~b}$ bolts that the

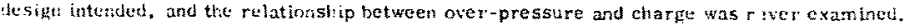

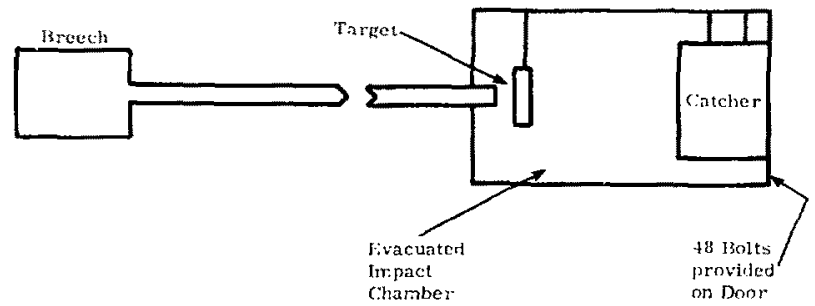

Figure A. Schematic of Cun Assembly in Original Design Configuration 
In 1977 a deslign change moved the catcher forwand from lts location against the rear door to a posttion just behind the target (Figure 7). This change was made to help coniine the producss of Impact to the target area for a longer time. When the gan was fired witr a nearly maximum charge. the cateher, upon linpact of the target, was torn lowse and impacted in the reas dixur. The force pulse from thls impact occured later in the time sequence than it orciriarit had dnise. when the lighter target was propelled into the catcher fastened to the door (Figure 51. Figure 8 is a schematic of the resulting force-eurve for the rear door compared to tho throretucal ablity of the door to withstand that force when fell, $4 b ; 7$ bills.

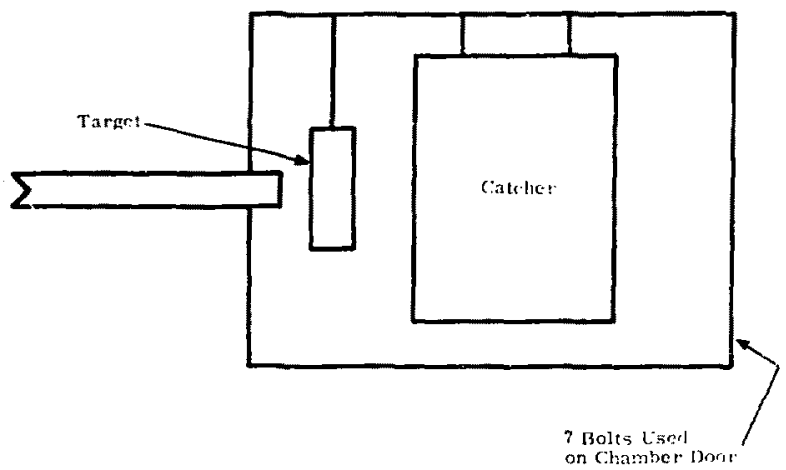

Fiaure 7, Impact - hamber Conditiest at Shot Tirre Shown Schematically

The result was that the nearly $2400-\mathrm{kg}$ rear door of the chamber was blewri copen with sufficient lisce to rupture the approxinately $13 \% \mathrm{~cm}$-thick steel hinge brackets. The angular momentum of the dopr caused severe misalignment of the whute, massive system, and the oterpressure released into the building housing the gun causted wall and ron sections to be blown ont flamuly ing the equipment in the area. Total damage was estimated at \$133.009. Sis personrel were in furer: because, as required by safe operating procedures, they we in a blockhutse located externath, to the gun facility at the time of firiag. 


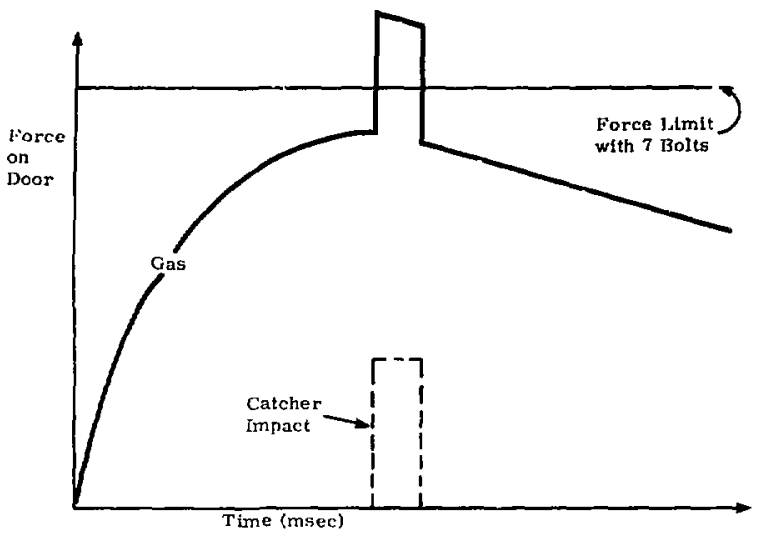

Figure 8. Furce on Chamber Door in Design Change Configuration

Looking at this incident from the point of view of a systems safety analogue, whic! , lso addresses operational questions, we structured our study of it to determine whether the incident could be attributed to "inadequacies" in any of the following:

- design,

- "ise" (implementation or maintenance) of design,

- saic operating procedures or practices, and/or

- the "use" or safe operating procedures or practices.

We also tried to determine whether there was sufficient assurance that no inadequacies in these areas existed. Here, "procedures and practices" were used as operational analogues of designs since they were the primary documented materials relating to how operations were to be conducted to promote sufety. "Practices" is used to denote institutional-wide requirements of a general, or programmatic. charactes, whereas "procedures" denotes project-specific requirements gencrated by the organization responsible for the facility, as required by institutional policy. 
In this tramework, we drew the following canclustons:

1. There were "inadequacies" in the deglgn.

- The orlginat deslgn was adequate from a rellabillty point-of-view. but was considered deficlent from the point of view of human engineering. It is unreasonable to belleve that persons will routinely fasten, by hand, 40 one-inch bolts .. particularly if it seems unnecessary. An "autoclave-type " hatch would have been preferable, and with suctl a hatch. the incident would not have tuccurred.

- The design configuration actually used las a result of the decreased number of bolts and the change in location of thecatche -) was elearly inadequate. Thie probabillty of failure was equal to "one" (Figure 8).

2. There were "inadequacles" in the "Lse" of the orighal design. The ur irinal design called for the use of 48 bolts and a lesser number was used. In addition, the original design called for the catcher to be against the rear door of the chamber. which also was changed. Without these changes i.e incident yould not have occurred. This was a reliability inadequacy.

3. There were "inadequacies" in sufe optrating procedures. Witten procedures designed to define actions necussary for safely operating the facility did not detine precisely the number of bolts to be used or give the qualification for using fewer than the specifivo 48. As a result, reviexers of the procedures assumed that all boits were heing used, but did not audit "use" of the procedures. The procedures failed to state any correlation between the explosite charge and number of holts used. $A$ simple failure modes and effects study for the design changes could have revealed these deficiencies. The procedures made no reference to the type or amount of training needed by operational personnel antl r.ade no provision, for ohtaining it.

In part, this is a haman factors deficiency becausa it is unrealistic to expect new personnol tn tolognize problem, without training. In part, his problem is die to administrative factors since institutional requiroments for nressurr safrty and rxplnsives safety training existed. Had personnel been trained in pressure saletv and explosites safety. thev should have begn more questioning about the adequary of design changes and their lack of inclusion in safe operating procedures.

4. There were "inadequacies" in the "use" of safe cperating prccedurts. The "use" of safe procedures was inadequate because the facility was not treated as a pressure facility as it should have heen, and was the refore not sunject to mandatory laborater: wide pressure safety practices by which significant design changes are reviewed. 


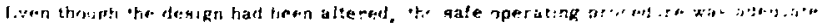
to provent ani injur.

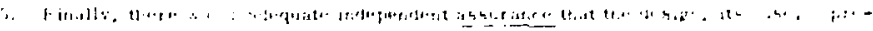

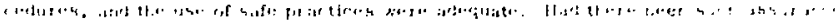

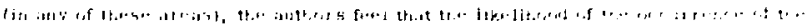

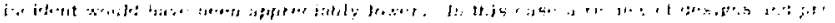

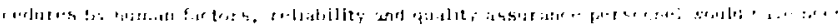

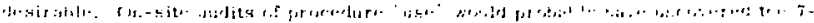

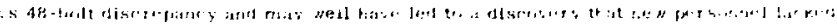

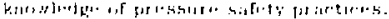

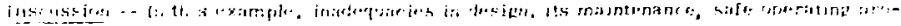

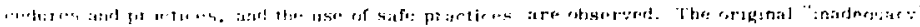

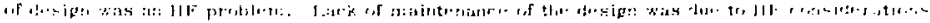

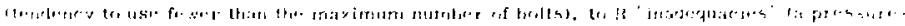

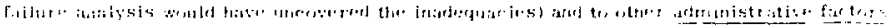

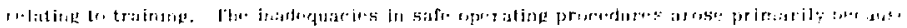

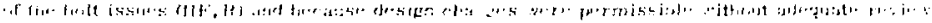

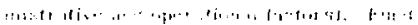

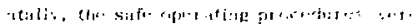

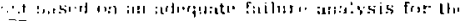

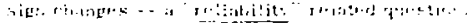

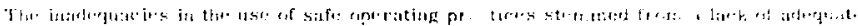

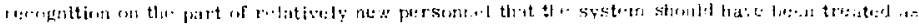

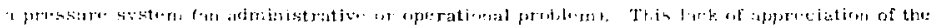

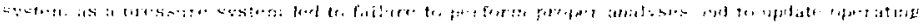

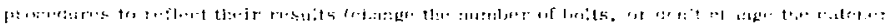

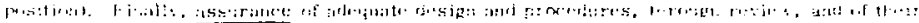

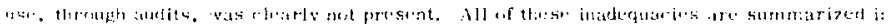

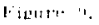

\section{$1:$ in:pir. $?$}

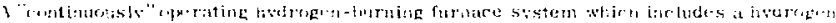

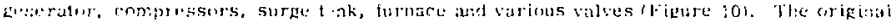

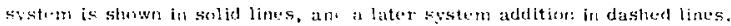

Sn the original system, the furnueve was operited comtinuously umil the crimpressor failed.

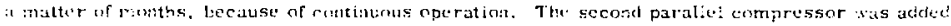
tu minimize dowr-time. Periodically, or if the uriginal compressnr failed, it was removed and stericed and the secind compressor was tised. 


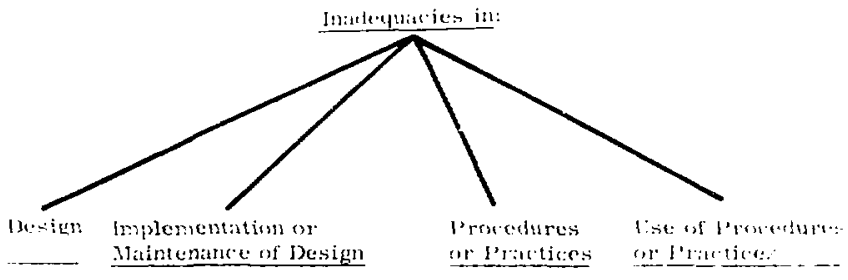

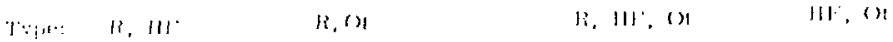

I. egend $(\sec \operatorname{tex})$ :

"H" - ronsideralion of failure morles ant! :onstequeneqs,

"HF" - consideration of situations which inselve preclictable humat

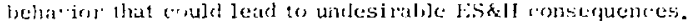

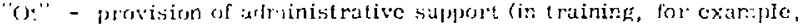

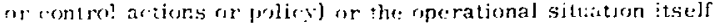

In addition, where inadequaries of $\mathrm{R}-$, IHF- or Ot-type existed, there *its a de fat to lack of assurance that the corresponding a reas (design, etc.) wore handlod adequately (sec :ext).

Figure 9. Sismmary of Inadequacies in fixamnle 1. 


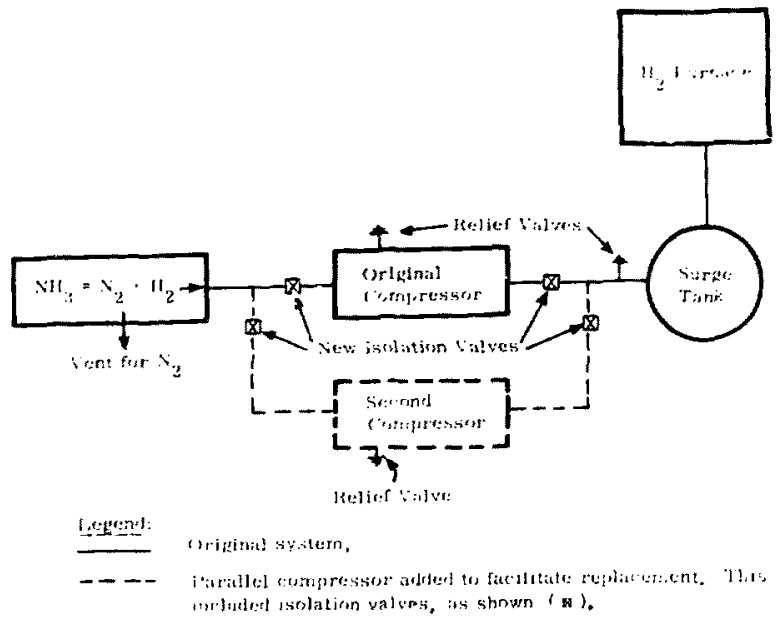

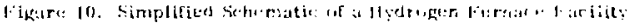

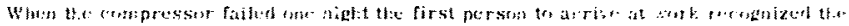

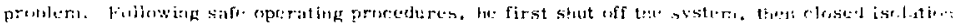

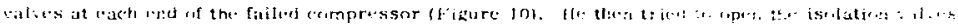

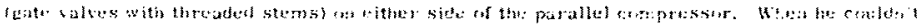

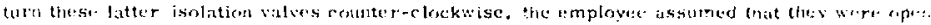

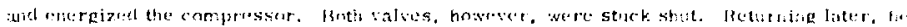

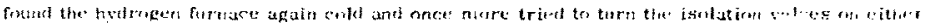

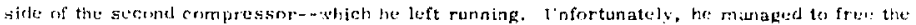

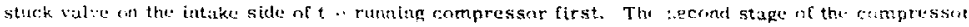

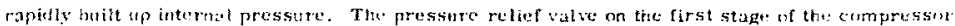
failet to furction, and the pressure rebief walve on the output side of the compressot was still

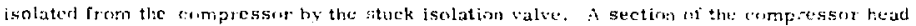
blew off. scittering shrapnet around the arta. The compressur noise pribr to tuis "explosidit" alurted the individual. causitg him to start ruming frum the room just as ine rompressor "bles."

Kecause the potuntially corrosive unisonment to which the relief valves were subjected was recognized, they had tieen scheduled, througl: the laboratory pressure safety program, for routine change-out witl: independently calibrated relief valves. New valves were rouinely ordered, checked, and shipped to the organization responsible for the hydroger furnace by the institution's pressure safety laboratory. In addition. the system was rontinuiy seruntinized by three separate safety committees and a trained "pressure safety advisor." 


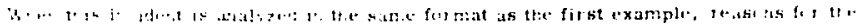

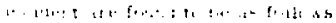

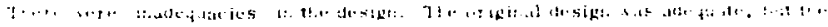
. •,

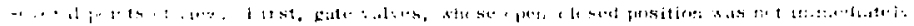

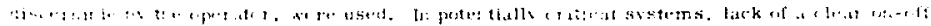

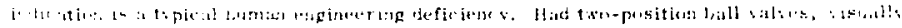

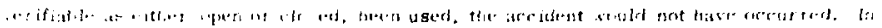

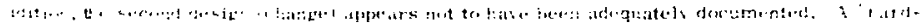

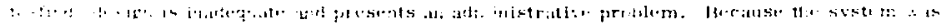

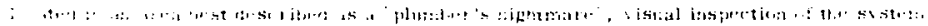

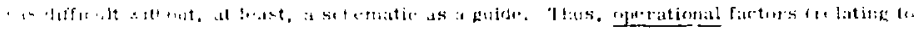

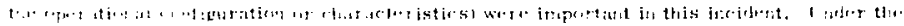

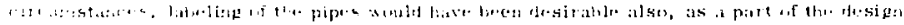

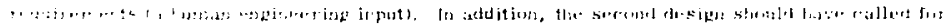

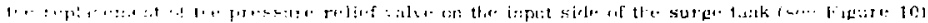

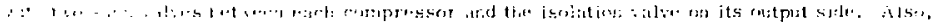

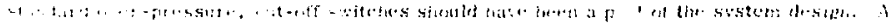

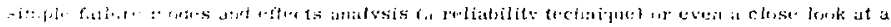

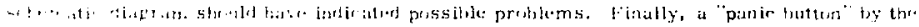

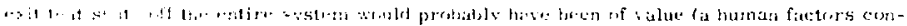
$211+1,1 ! \cdots, 1$.

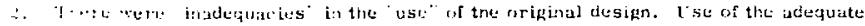

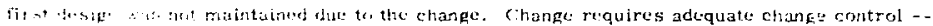
Mhill in thic rate, was not drfined. In addition, the falure to maintain properly npe rating

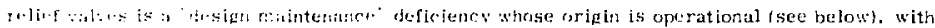

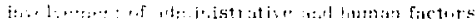

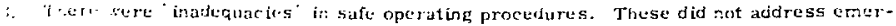

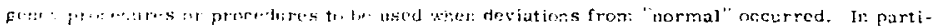

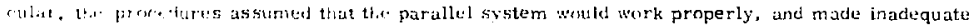
prrisir: for stutting down the sistem when the original system fuiled. Since procedures did reruirc shutdewn before change-over, the system should have heen shut down under these abnormal

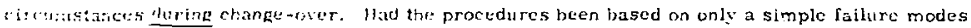

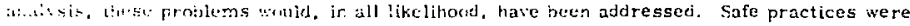

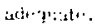

4. There tvere "inadequacies" in the "use" of botti safe operating procedures and practices. Both sate pructices in the institution and the safe operating procedures called for a routine changeoul of the pressure relier valves on the compressors. A system was set up to provide tested 


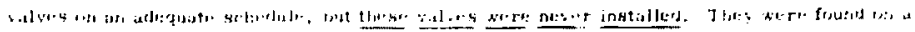

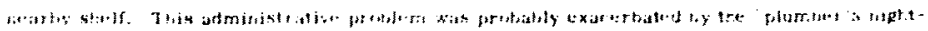

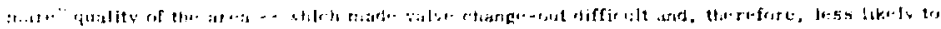

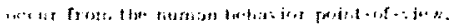

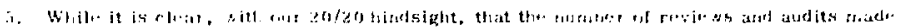

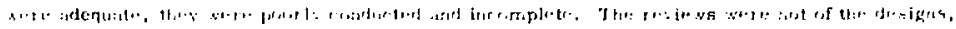

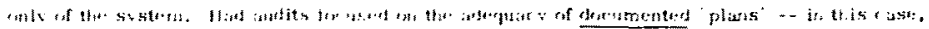

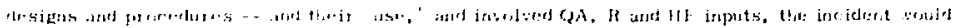

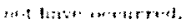

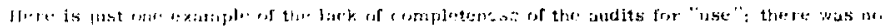

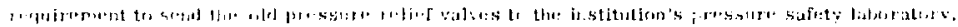

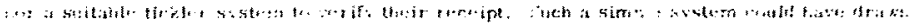

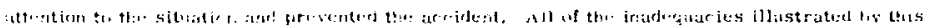

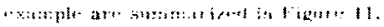

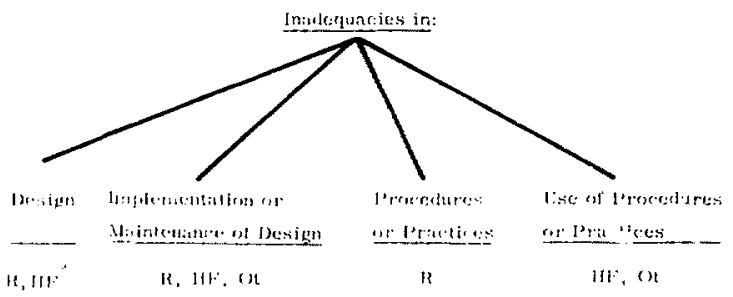

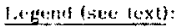

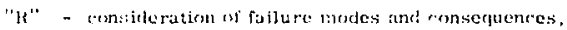

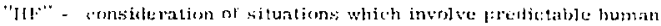

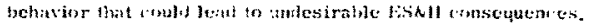

"ot" - provisiun of asministrative suppott fin training, for example.

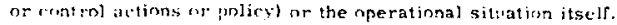

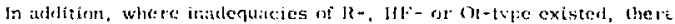
was i de facto lack ai assurance that the corresje nding areas d design, etc.? were hindled idequately (soe text).

Fugure 11. Sum:nary of Ingriequacies in t:xample 2. 


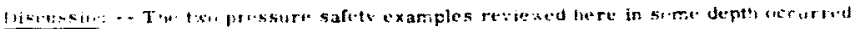

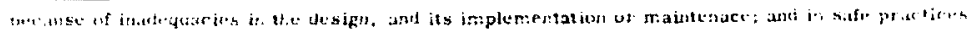

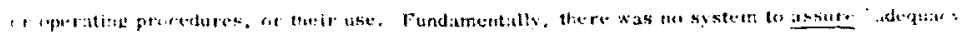

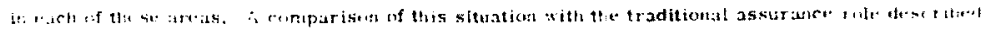

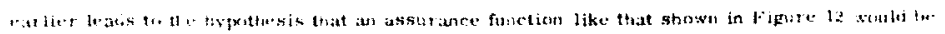

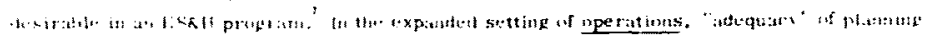

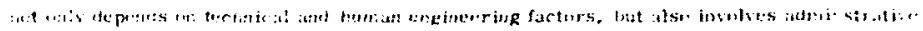

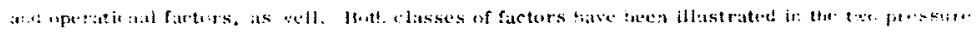

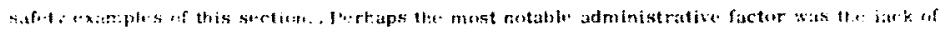

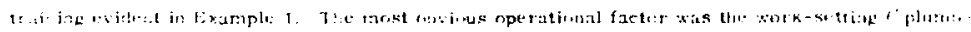

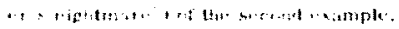

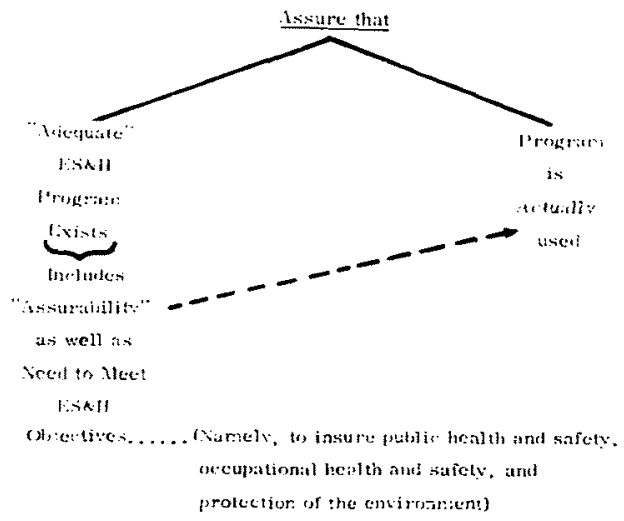

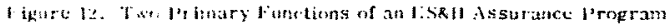

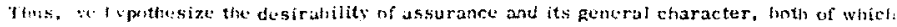

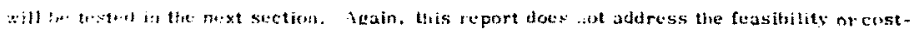

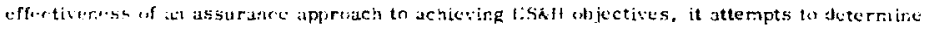

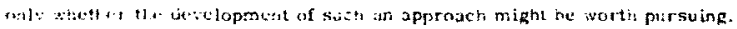

A S. nmary or Twent

Twentr-three wher incidents were examined in someshat the same fashion as thi examples of the previtas section. They are pruscnted here in much less detail. Accident investigation reports were used almost exclusively as the source of infrimation and the basis tar judgment i: thicse 23 incidents, whercas, in the exanples of the previous section, some interviews wert insolved as well. Rrief descriptions of try incidents and explanations of our findings follow. 


\section{Mrief Incident besc:iptions ant Findingu}

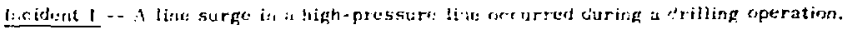

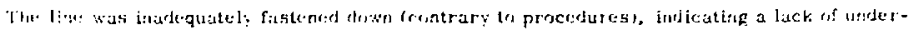

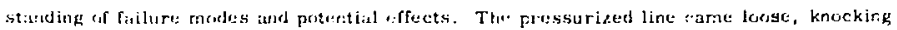

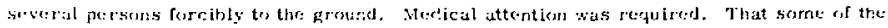

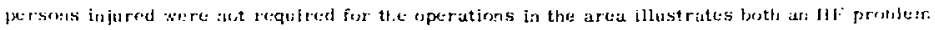

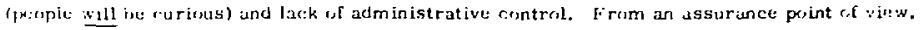

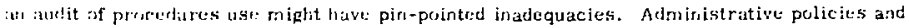
partices (flF ticold have been revinwed for the ir adequacs in contrulling unnecessury personnel

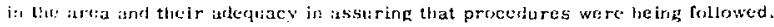

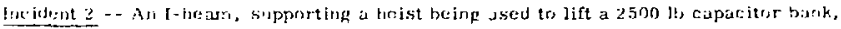

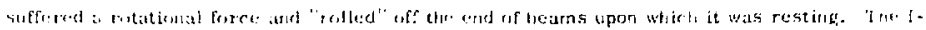

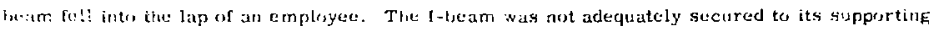

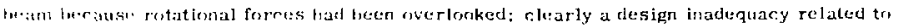
fisilure-mode identification. Ir addition, the resporsible organization did not tollow safe sperating prirtices in mplementing thu design tan administrative issue). With respect to assurance, the likr-jit.cord that such a design fault rould an unnoticed decreages significantly when "rother spceialties" (i,", HF, QA, RA, Siffety) ruview eonditions.

Inririunt 8 - A painter was wrot-ing on scaffolfing irsiste a 100, 000-gal water tank, the top uf which was $150 \mathrm{ft}$ abche the grounte. In the last mose of planks on the scaffolding before: finisting the inh, the painter etiscennested his lifeline and plank-securing clampis at the same time. [n combination, thusi actions iolated safe practices, as did the fact that the painter was alone in the tunk. wable tre communisate with his belper outside on the ground, The painter foll

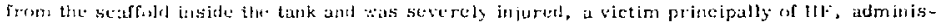
trative, and operitisually urimated doficiencies.

Iticident 4 - - is person esteret an exclusinn target area of a high-pulse radiation devicu

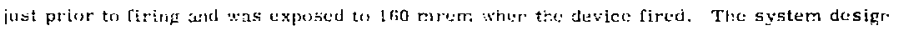
permitter entry aud firing ia spite of interlocks, bucause the interlock system was in.uperative d. riag an autnmatic $10-\mathrm{s}$ countiown period prinr to fiz reach the tareot area, the indiviaual l:ad to pass a gate. which was unlocked contrary to requiremeits of sace operatirg procedures. The upenirg of this gate prior to the 10-s automatic countdiw: would have actuated the interluck system. and made firing impossible, but the employed's timing :us impeccable. Worst of all, tl:e indivitiul entered the area only because he rad nisinderstom oral directions (not covered in operating procedures) - a common llF concern. From the standpoint of assurance, a properly conducted design review should have caught the interlock duficiency, and auditg of the use of procedures mlght have prevented the existence of the unlocked gate. 
Incident 5 - A workman slipped on a tanker ladder rung and injured his leg. Tlue rungs were located tro close to the tanker body to permit safe placement of feet; a design acticiency f:nm the $\{1 \mathrm{~F}$ (physiologicall point of siew. In acitition, tite wrorkman apparuntly hud nil on th: soles of tis sl:oes, indirating puor safe-housekewping practices.

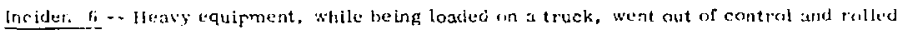
from the truck, dar.iging a nearhy fence and the equipment itself. Pirsonnel, who w.re the all

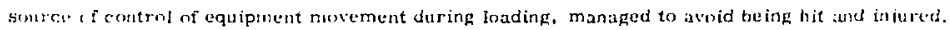
A simple safety analysis ("what if -.-?") woule probahly bave indicoted that some merianicul control of mesentent was desirable, la this case, no safe "periting procedures sxisted for the sperific operation, ind situ practires were violuted.

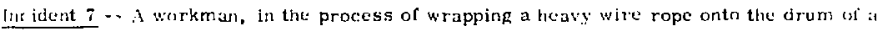
hoist, unintentinnally actuated a fort switch which started the drum turning. llis finger was raugh in tlu" winding wire rope and moshed. The accident could have been avided by it design

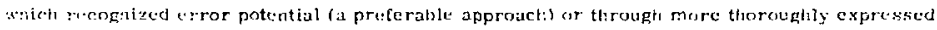
procediuges.

[:arirlint 4 - I material handler, transporting a 290-1h capacitur on is hand truck, slipped aud lost control of the rart. The cupacitor fell from the cart ancl st ruek an employce, ciusing it sewre gast in this leg. The original slip was caused by oil on the sole of the material thandler's showe. Endirating pror use of safe practices in the area. Nso, the capaciter was not secured

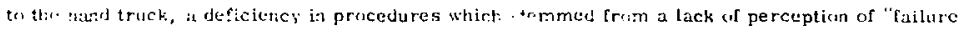
moti:s" ard their consequerices.

Ificident :- in instrumented manned helium hallon was being used to study atmospheris polluturt.s. Inst prine to launch, and in accordance with plans, a man was placed on the railing of tha: gnadelia as ballast until launch tire. The countdewn to launch was unheard by the person, and the thether was released aithout warning. When the "human ballast" realized that the balloon was -isine. fo nisiudged its beiglt filecause he wus wearing biofocalst and suffered a fractured ankli: wen me feil. Flintsight indicutes that the plan was inadequate and should have been reviewed. The re were he sale operating procedures or analyses fan administrative problem), and the lack uf conmuitiation at launch was a human cror.

madent 10 -- A machinist was turning a heavy, oversized part on a lathe. The mandrel taled and thr: part disintegrated, scatturing pieces forcefully. i safo operating procedure was necdeel whick recognized limitations m the equipment. In addition, there was a design deficiency in t:e mandrel. which was made of soft woud with a faceslatc attached by screws that were sunk into glue joints. Although considerable energy was released no injury occurred. I design revicw would have been appropriate 
Incident 11 - A catastrophic fallure of a self-hreakdown, gas, highi-power 12 MI: several hurdred thessind $A$ switch in a large coaxial line causel the forable separation of a seetion of the calaxial line and the 1 . 8-m movemest of $1800 \mathrm{~kg}$ of lint and attaciad equipment. Nes one was injures. The fallure recurretl as a result of a high-voltage breakdown in the high-pressure (11 atm) gus switch which caused a fracture of the acrylic brousing of the gas chamber. permitsing

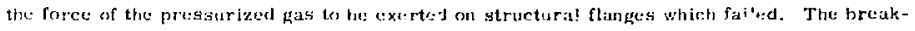
down was largely due to tlak accumulation of dust as a result of infrequent maistenance. In addition. a lack of a pressure rolief valve for the gas was a design duficiercy.

Inridest 12 - - The damages he atd of a herizontal cask was being removed, involving the ust:

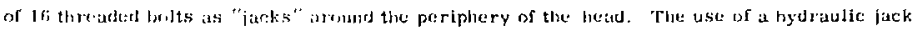

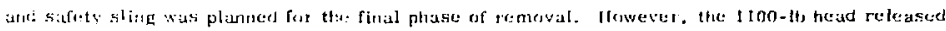

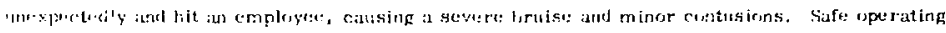

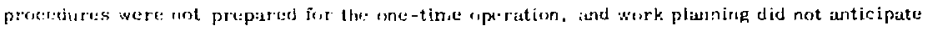

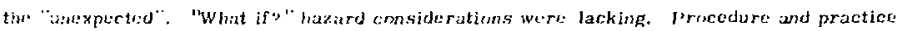

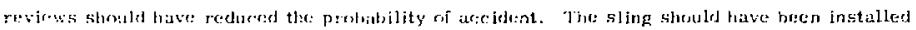

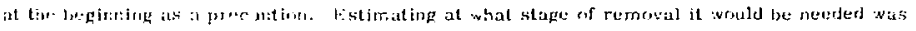
at best att unsaff: Lutsis.

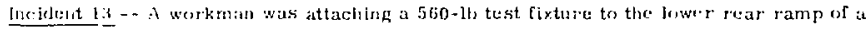

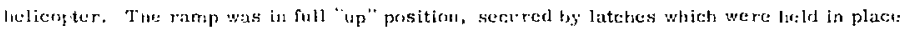

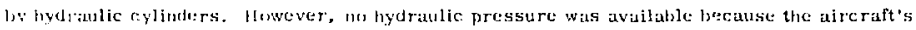

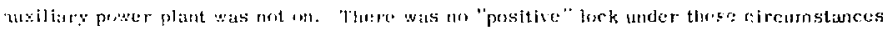

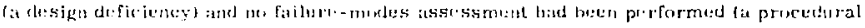

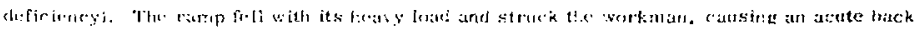
sit:ui:i,

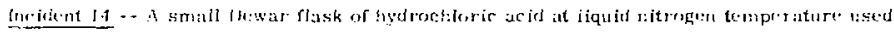

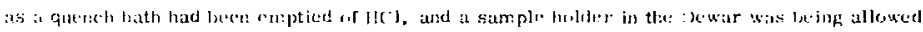

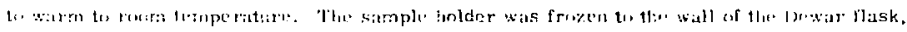

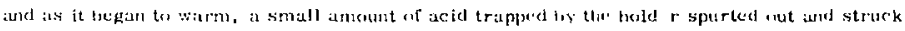
a terhnician in the est. The indjoidual was not wearing safety glassiss, as required by safe

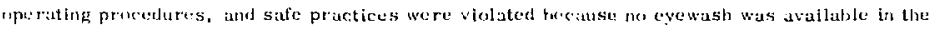
areas. A sufety shiceld was not included as a part of the equipment design.

Lucident 15 - - While a machinist was grinding the cutting edge of al lathe-turning tool, the

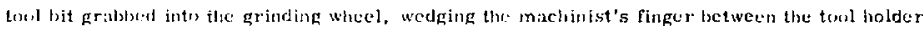
and the grind: $\mathrm{r}$ table. A broken hone and lace rations resulted. Investigation revealed that the tool hit had rat hece properly prepared ard the grinder l:ad heen improperly maintairied and inadequately inspected prior to use. 


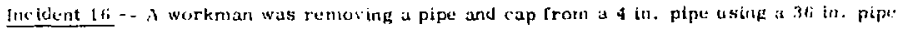
wrench. The wronch slipped und the worknan's fitogers were masted between the wronch ind

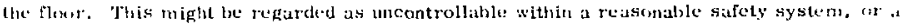

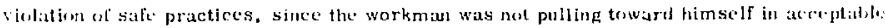

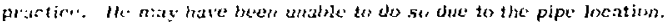

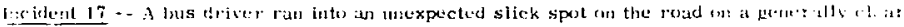

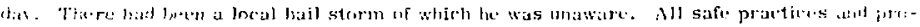

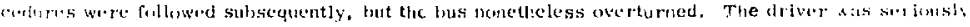

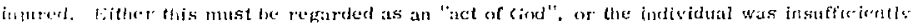

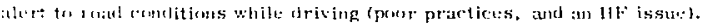

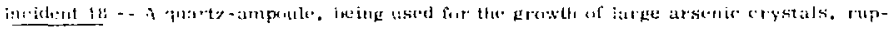

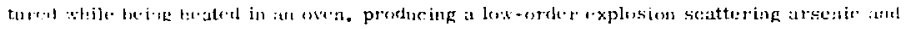

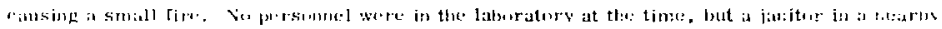

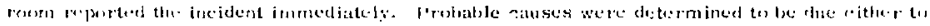

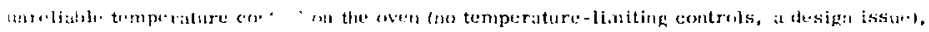
ur to fitigue influced in a quirty-ampoule due to an interaction with arsenie ur to repeated ligh

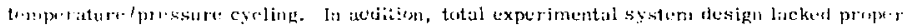

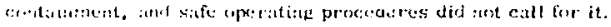

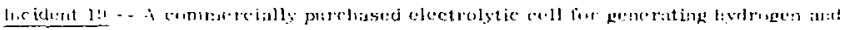

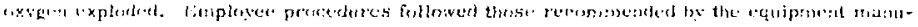

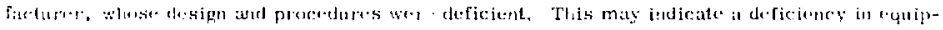

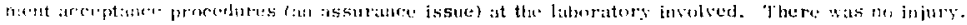

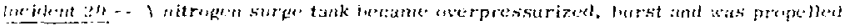

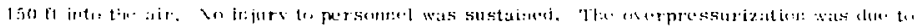

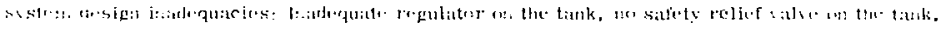

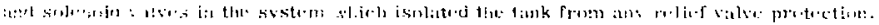

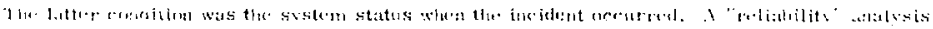

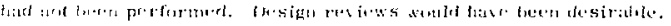

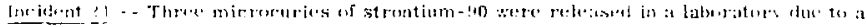

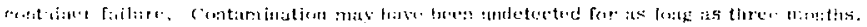

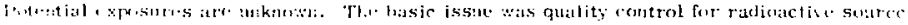

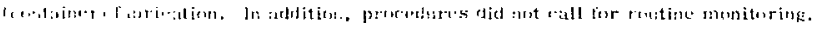

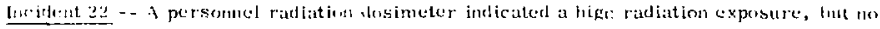

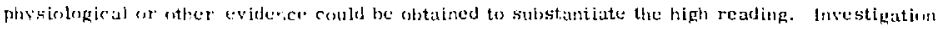
de:tr.mined that it was bighly probuhle that the dosimeter had been exposed only as at result of

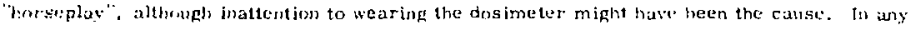
event, the issue is ont of inadequate use of sale practicies in a radiation facility. 
Incident 23 - - Scveral individuals were exposed to radiation from a small cobalt-60 source. The source was part of a portable radiation desice in which the collimator was attached to a shielded source tube by a hose. The snurce was run from the tube to the collimator during uke, and back to the source tubu befure personnel were allowed near the devict, After operation, the returrs of the source t. the cuide was incomplete due to a delect in the suree retracting mechanism, which construined the source in the hose. Personnel assumed that the source has returaed to the tulu and entered the rom containing the device. Vo toliation monituriug

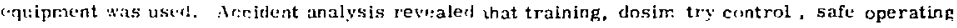
procedures uni adrinistrative controls vere all "less than adequate.

\section{Sunmar'y und Conclusions}

"Table I smmmarizes our findings rel lted to the 23 incidents inves igated in this study. Thest incidents are largely industrial safety oriented, but do intersect the areas of fire protection. industrial hygiene and health physics as well. The primary concern, in all cases, was potential in jury to the employte and to property. However, due to the nature of the incidents, these concterns, and any mrrective actions, are equally applicable to public health and safety and [entironmental protection. In Tible $T$, the designations of $R$ or $H F$, in categories relating to besign, represtent inardequacies in the truditional system safoty sense discussed in section 1 .

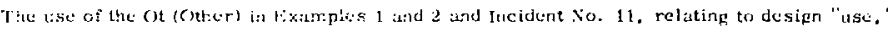
indicates a lack of clatiag cuntral nr training. [n attempting to "translate" these designations inte maningful categrerics ir an opu tatioral setting, generally they are used to indicate inculicitiacies iv:

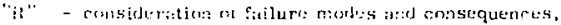

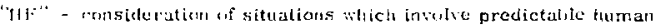

$$
\begin{aligned}
& \text { behavior that could lead to undesioble liskil censciquences. } \\
& \text { "Gu" - provision of administrative suppirt liu training, for example, or } \\
& \text { control actions or policyl or the operatıonal situation itself. }
\end{aligned}
$$

We Jeadily admit thut the assigument of these dosignations $k$, the "procedures and practices" catchoriss is highly subjective, tut in our best judgment, they can be so assigned meaningfully ind fully coner the generic nature of inadequacies. Finally, the use of $\because \therefore$ in the last eolumn nf ' 1 :able I indicates that, in bur best judgment, no realistic coutrol conld be exercised to prevent

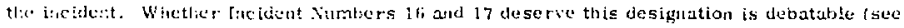
th: previous scetion?. 
TABLE: 1

Catrorizative of licident causes thee text for explanatlon where entries ocetur: theren was a concoinitant lack of assurauct)

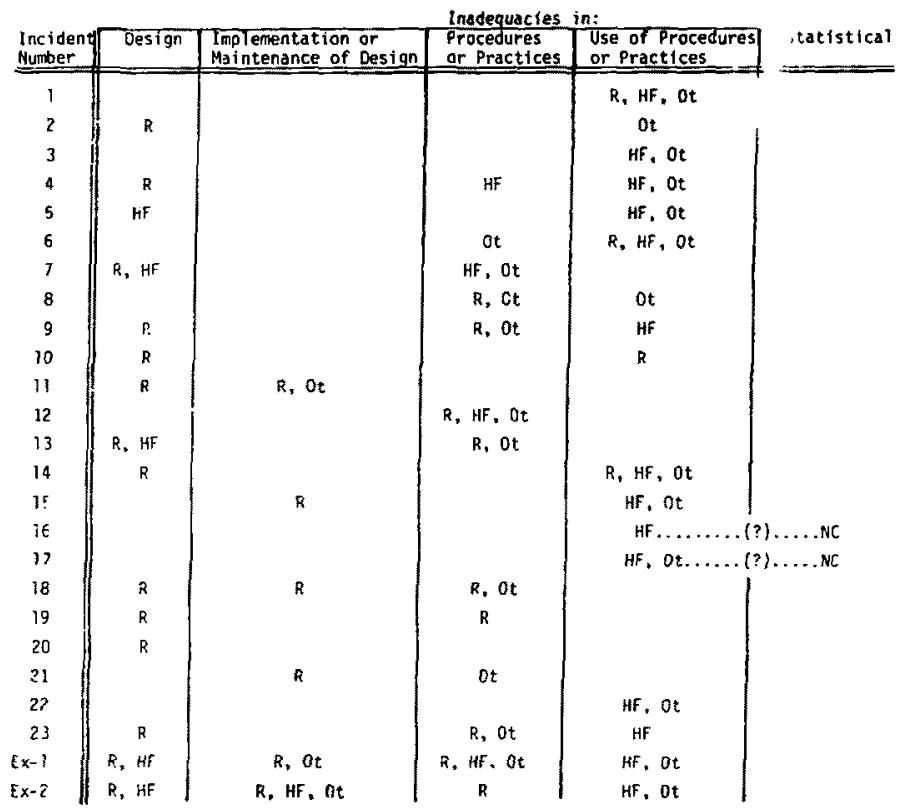

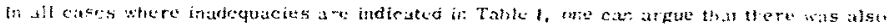
an inadeguacs in assuring proper drsign, its implemintation, and so furth. luuc bad such assurane bet n present, we assert that the axpurrente of carh of the incidonts exatinet, with the possible "xeption of Xumbers 16 and 17 , would have bren much less likely.

Carvine this a step farther. Tahli II presents a "statistical summary of the results

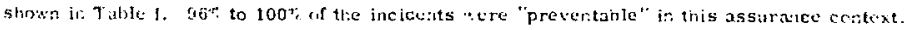
Witheut a detailed discussion. we conelude that the development of at atologue of systems

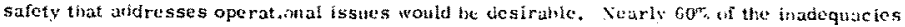
Here found in the "operational" categuries assuciated witin procedures and practices. Nore significanty perhaps of the 23 incidents that were judged to be clearly due to inarlequacies 
(that is om ittirig Yos. 16 and 17 ), 21/23, or over $91 \%$ could have been mitigated by attention to operations alone, whereas only $17 / 23$, or about 74 \%ould have been addresged by attention to systems safety (design) alone. These data suggest, for those wlllirg to extrapolate from a relatively small dat u bse. that equipment lnadequacies are more likely to occur in organizations that have operational inadequacies than in organtzations that have none. This firding is, periaps. not unveasonable since assurance that design is adequate and maintained is an operatlonal activits.

TABILI: II

ISriof Analysis of inciden. Causes

Inadequacies In:

Totals
Percentages

Finally, a nualificution. Clearly, hinsight is a nuch hetter basis for artalysis than foresight While we have atcoipted to afulyoe these inc idents in tarms of inadequacies that we believe whallie recognized by $Q A$, $R$, or IIF spucialists, in crmbitation with persons skilled in the Eisku relinted disciplines, ther. is little in the way of proif that this is so. With this caveat we conclude from the results of Tubles 1 and II that an lisill assurance program designed to assure the adequacy of

- cusign.

- its inplementititir. and maintenance.

- sale nperatios procedures and practices, and

- their use.

wnifle appear to be a theoreticany desirathe concept, and that plarning for such an activity shomlit in: undertaken, wal the cust-eftectiveness of such plans stulied.

A further conclusion of comsiderais!e importance that may be drawn fron: this study relates in the role of risk allyeis in aerident prevention. Table 1 suggests that "Reliahility" Is an important facet of accident preventior. As discussed in the text, the major nzed relating to $R$ was, in all appropriate cases, an understa-ding of failure modes and generic etfects. Vowhere, th our cunsidered opinion, would prevention of the accidents studied here have necessitated a quantitative risk analysts in w: teh each potential consequence was understoud in terms of its probability of occurrence. Thus, considering the limited scope of this study, we can conclude 
tentativeiy that risk analysis (when this term is used to denote quantification of risk vs consequenceg) offers relatively few benefits for accident prevention, This, to us, suggests that efforts to join in the increasingly popular activity of "risk analyais" should ise undertaken with carce and discrimination.

Ih closing. it is perhaps well to point out, for those familiar with other approaches to accident investigation, that there is less difference between the ultimate categories of concern studied inere and those found in other approaches than might be apparent at first. Cuneric analysis of why procedures are not used. for example. leads one to consider familiar inadetauaries in administrative support, policy, motivation, communication, training, and so forth. Thus, a program designed to achieve use of adequate procedures must have these familiar elements. Philosophically, however, the focus of an assurance approach based on system safety principles is very different. The emphasis is on a structured approach to independently assuring that the meeded clements of an ESEII program are adequate and used. In this context. policy. trainiag. and $s$ forth $c$ an be derived (as just suggested) as necessary and sufficient elements. Whose zistence and adequacy is to be indeperdently judged. In this way, many of the familiar element: of "accident-prone" theories (Ruference 2 ) or management oversight and risk trees (Pe.Perence 3 ) becume elements of logically derivable "checklists" to be used in assurance roviews and audits.

Sinc: the fixdings piestented here were first obtained carlet this year, consile table proaress has been made toxard defining and testing the generic elements neeced in atl a ssurance approdeft to lisk 1 program Management. Descriptions of this work whl he found in References 1 . $4,5,1 i$ and 7 . 


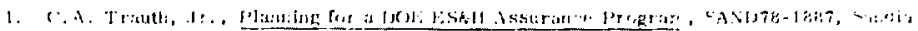

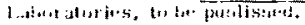

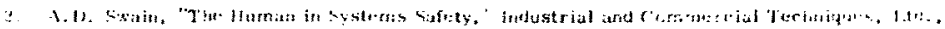

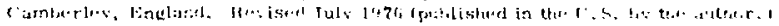

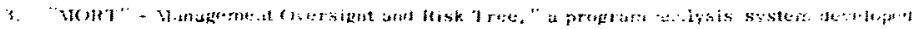

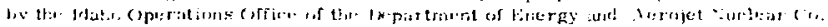

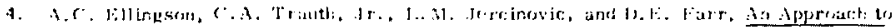

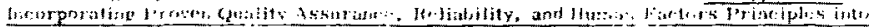

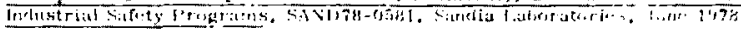

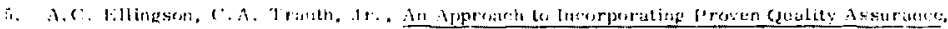

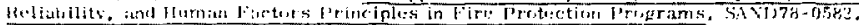

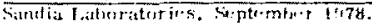

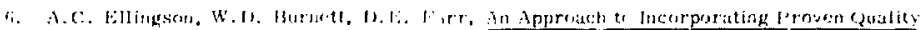

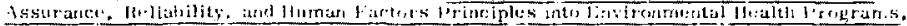

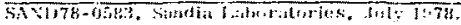

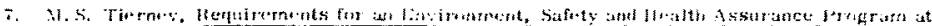

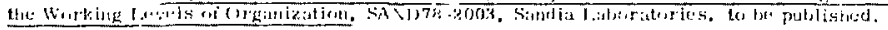

